\title{
PENGGUNAAN METODE DEMONSTRASI UNTUK MENINGKATKAN HASIL BELAJAR IPA SISWA KELAS VI PADA MATERI GAYA DAN GERAK DI SDI HABIRATIN
}

\author{
THE USE OF THE DEMONSTRATION METHOD TO INCREASE THE VIEW \\ STUDENTS' SCIENCE LEARNING OUTCOMES IN STYLE AND \\ MOVEMENT IN SDI HABIRATIN
}

\author{
Fransiska Blupur \\ SDI Habiratin, Desa \\ Talibura, Kec. \\ Talibura Kab. Sikka \\ NTT, Indonesia \\ blupurfransiska@gma \\ il.com
}

IJI Publication p-ISSN: 2774-1907 e-ISSN: 2774-1915 Vol. 1, No. 3, pp. 238242, Juli 2021

Unit Publikasi Ilmiah Intelektual Madani Indonesia
Abstrak: Tujuan penelitian ini adalah untuk meningkatkan hasil belajar IPA siswa kelas VI khususnya pada materi gaya dan gerak di SDI Habiratin. Beberapa hal yang dapat dilakukan guru agar pembelajaran menjadi lebih bermakna bagi peserta didik, antara lain: memiliki metode strategi dan model pembelajaran yang sesuai sehingga dapat menemukan yang sesuai bagi dirinya. Apabila guru telah menemukan model strategi, metode yang tepat dan sesuai bagi dirinya dan anak didik maka suasana pembelajaran menjadi lebih kreatif, dinamis, tidak monoton dan menyenangkan, sehingga dapat memberikan rasa puas bagi anak didik. Dampak selanjutnya adalah pemahaman terhadap konsep-konsep IPA yang dipelajari anak didik menjadi lebih bermakna, lebih kuat dan berdaya guna, sehingga hasil belajar anak didik menjadi lebih baik. Salah satu model pembelajaran yang dapat dilakukan guru adalah metode demonstrasi. Subjek dalam penelitian siswa kelas VI SDI Habiratin semester I tahun pelajaran 2019/2020 yang terdiri dari 12 siswa. Prosedur penelitian yang digunakan yaitu prosedur jenis penelitian tindakan kelas yang dilaksanakan dalam 2 siklus, setiap siklus terdiri dari 4 tahapan yaitu perencanaan, pelaksanaan, pengamatan, dan refleksi. hasil belajar siswa yang tergolong dalam kategori tuntas pada tes pendahuluan hanya 46,87\% (5 Siswa), siklus I sebesar 75,00\% (7 Siswa) sedangkan pada siklus II mencapai $96,87 \%$ (10 Siswa), dengan demikian kategori hasil belajar siswa yang tergolong tuntas mengalami peningkatan sebesar $21,87 \%$. Hasil belajar siswa yang tergolong dalam kategori tidak tuntas pada siklus I sebesar $25,00 \%$ (3 Siswa) sedangkan pada siklus II sebesar 3,13\% (0 Siswa) dengan demikian kategori hasil belajar siswa yang tergolong tidak tuntas mengalami penurunanan sebesar $21,87 \%$. Sehingga dapat disimpulkan bahwa penggunaan metode demonstrasi pada mata pelajaran IPA materi Gaya dan Gerak dapat meningkatkan hasil belajar siswa kelas VI SDI Habiratin.

Kata Kunci: Metode Demonstrasi, Hasil Belajar.

Abstract: The purpose of this study was to improve the science learning outcomes of sixth grade students, especially in the matter of force and motion at SDI Habiratin. There are several things that teachers can do to make learning more meaningful for students, including: having appropriate strategy methods and learning models so that they can find what is right for them. If the teacher has found a strategy model, the right and appropriate method for himself and his students, the learning atmosphere becomes more creative, dynamic, not monotonous and fun, so that it can provide a sense of satisfaction for students. The next impact is that the understanding of the science concepts that students learn becomes more meaningful, stronger and more efficient, so that students' learning outcomes are better. One of the learning models that can be done by the teacher is the demonstration method. The subjects in the research were the sixth grade students of SDI Habiratin in the first semester of the 2019/2020 school year, which consisted of 12 students. The research procedure used is a classroom action research procedure which is carried out in 2 cycles, each cycle consisting of 4 stages, namely planning, implementation, observation, and reflection. student learning outcomes belonging to the complete category in the preliminary test are only $46.87 \%$ (5 students), the first cycle is $75.00 \%$ (7 students) while in the second cycle it reaches $96.87 \%$ (10 students), thus the result category student learning that is classified as complete has increased by $21.87 \%$. Student learning outcomes belonging to the incomplete category in the first cycle of $25.00 \%$ (3 students) while in the second cycle of $3.13 \%$ (0 students) thus the category of student learning outcomes classified as incomplete decreased by $21.87 \%$. So it can be concluded that the use of the demonstration method in the science subject matter of Style and Motion can improve the learning outcomes of grade VI students of SDI Habiratin.

Keywords: Demonstration Method, Learning Outcomes. 


\section{PENDAHULUAN}

Pembelajaran sebagai suatu sistem instruksional mengacu pada pengertian sebagai perangkat komponen yang saling bergantung satu sama lain untuk mencapai tujuan. Dalam suatu pembelajaran terdiri dari perangkat pembelajaran yang saling berkaitan dan bertujuan untuk mencapai tujuan pembelajaran yang telah ditetapkan. Perangkat pembelajaran harus sesuai dengan tujuan pembelajaran yang ingin dicapai dalam proses pembelajaran untuk mengarahkan peserta didik dalam melakukan proses belajar.

$$
\text { Puskur Depdiknas }
$$

mendefinisikan IPA sebagai "pengetahuan yang sistematis dan tersusun secara teratur, berlaku umum (universal), dan berupa kumpulan data hasil observasi dan eksperimen". IPA sebagai salah satu mata pelajaran di sekolah dinilai sangat memegang perananpenting karena IPA dapat meningkatkan pengetahuan siswa dalam berpikir secaralogis, rasional, kritis, cermat, efektif, dan efisien. Oleh karena itu, pengetahuan IPA harus dikuasai sedini mungkin oleh para siswa.

Ilmu Pengetahuan Alam (IPA) dapat didefinisikan sebagai proses ilmiah, sikap ilmiah, dan produk ilmiah, Ilmu Pengetahuan Alam (IPA) sebagai proses terdiri atas berbagai produk keterampilan, yaitu keterampilan proses dasar seperti mengamati dan mengukut, serta keterampilan proses terpadu meliputi: merumuskan masalah, menarik kesimpulan dan sebagainya. Sementara itu Ilmu Pengetahuan Alam (IPA) sebagai sikap menuntut siswa untuk memiliki sikap ilmiahnya seperti jujur, teleiti, kritis mampu bekerja sama dan sebagainya.

Sebagai produk memiliki komponen yang terdiri atas hukum dan teori. Di dalam hukum dan teori itu terdapat komponen yang lebih kecil lagi, yang disebut konsep. Konsep merupakan produk dari proses ilmiah. Secara sederhana dapat diilustrasikan sebagai berikut: siswa melakukan pengamatan dalam proses, dan proses ini akan menghasilkan fakta. Dari berbagai fakta yang diperoleh dibuat generalisasi sehingga terjadilah konsep. Jadi konsep dapat didefinisikan kumpulan stimulus (benda, peristiwa dan lain-lain) yang mempunyai ciri yang sama.

Betapa pentingnya memahami konsep bagi siswa dapat dilihat dari dicantumkannya pemahaman dan penerapan konsep di dalam setiap jenjang pendidikan. Konsep adalah kemampuan siswa yang memungkinkan siswa dapat berbuat sesuatu. Ini dapat diartikan bahwa tanpa menguasai konsep mata pelajaran Ilmu Pengetahuan Alam (IPA) siswa tidak dapat berbuat banyak dan mungkin kelangsungan hidupnya akan terganggu. Contoh yang sederhana, apa yang akan terjadi jika siswa tidak bisa membedakan antara air dengan minyak, antara tumbuhan dengan hewan, antara gula dengan pasir, dan antara madu dengan racun.

Dari uraian di atas jelaslah betapa penguasaan konsep-konsep Ilmu Pengetahuan Alam (IPA) dan juga ilmu yang lain bagi kelangsungan hidup dan peningkatan kesejahteraan manusia, baik di masa silam maupun masa yang akan datang, terlebih bagi bangsa Indonesia yang mau atau tidak mau harus mampu bersikap dalam memasuki era pasar global. Kegiatan belajar mengajar tidak terlepas dari berbagai permasalahan, diantaranya adalah rendahnya hasil belajar siswa dan pemilihan model pembelajaran yang kurang tepat, sehingga siswa kurang memahami materi pelajaran sesuai dengan kompetensi dasar yang ditetapkan.

Upaya untuk meningkatkan prestasi siswa dalam kegiatan pembelajaran harus ditempuh guru. Proses pembelajaran yang dilakukan oleh guru mampu menarik perhatian para siswa. Proses belajar mengajar yang tidak menarik dapat mengakibatkan kejenuhan pada diri siswa. Bila ini terjadi, sudah pasti prestasi siswa tidak dapat 
ditingkatkan. Untuk dapat meningkatkan prestasi belajar siswa, maka guru harus merubah proses belajar mengajarnya, dari proses yang menjenuhkan menjadi proses belajar mengajar yang menarik bagi siswanya.

Beberapa hal yang dapat dilakukan guru agar pembelajaran menjadi lebih bermakna bagi peserta didik, antara lain: memiliki metode strategi dan model pembelajaran yang sesuai sehingga dapat menemukan yang sesuai bagi dirinya. Apabila guru telah menemukan model strategi, metode yang tepat dan sesuai bagi dirinya dan anak didik maka suasana pembelajaran menjadi lebih kreatif, dinamis, tidak monoton dan menyenangkan, sehingga dapat memberikan rasa puas bagi anak didik. Dampak selanjutnya pemahaman terhadap konsep-konsep IPA yang dipelajari anak didik menjadi lebih bermakna, lebih kuat dan berdaya guna, sehingga hasil belajar anak didik menjadi lebih baik.

Salah satu model pembelajaran yang dapat dilakukan guru adalah metode demonstrasi. Metode demonstrasi adalah metode yang digunakan untuk memperlihatkan sesuatu proses atau cara kerja suatu benda yang berkenaan dengan bahan pelajaran (Syaiful Bahri Djamharah, (Trianto 2010). Hasil belajar merupakan bagian terpenting dalam pembelajaran. Nana Sudjana (2008) mendefinisikan hasil belajar siswa pada hakikatnya adalah perubahan tingka laku sebagai hasil belajar dalam pengertian yang lebih luas mencakup bidang kognitif, afektif, dan psikomotorik.

\section{METODE}

Subjek penelitian ini adalah siswa Kelas VI SDI Habiratin tahun pelajaran 2019/2020. Jumlah siswa sebanyak 10 siswa yang terdiri dari laki-laki 9 orang dan perempuan 1 orang. Penelitian ini berbentuk tindakan yaitu kerjasama antara peneliti dengan teman sejawat. Menurut Sunardi (2010), penelitian tindakan kelas adalah penyelidikan secara sistematis dan terencana yang dilakukan guru untuk memperbaiki pembelajaran di kelasnya dengan jalan mengadakan perbaikan dan mempelajari akibat yang ditimbulkan.

Penelitian Tindakan Kelas (PTK) ini menggunakan dua siklus. Hal ini direncanakan agar dalam proses belajar mengajar diharapkan hasil belajar dapat mencapai peningkatan. Siklus pertama dilakukan sebagai acuan refleksi terhadap pelaksanaan siklus kedua, sedangkan siklus kedua dilakukan untuk meyakinkan hasil penelitian yang telah dilakukan dan untuk membuktikan bahwa pelajaran dapat digunakan dalam indikator yang berbeda dalam materi yang sama.

Dalam penelitian ini menggunakan skema penelitian Hopkins dimana penelitian tindakan dilaksanakan berupa proses pengkajian berdaur (cyclical) yang terdiri dari 4 tahap. Siklus dalam tindakan kelas diawali dengan perencanaan (planning), penerapan tindakan (action), observasi (observation), dan refleksi (reflection). Keempat langkah utama dalam PTK yaitu perencanaan, tindakan, observasi/mengamati, dan refleksi merupakan satu siklus dan dalam PTK siklus selalu berulang. Setelah satu siklus selesai, mungkin guru akan menemukan masalah baru atau masalah lama yang belum tuntas dipecahkan, dilanjutkan ke siklus kedua dengan langkah yang sama seperti pada siklus pertama. Dengan demikian berdasarkan hasil tindakan atau pengalaman pada siklus pertama guru akan kembali mengikuti langkah perencanaan, tindakan, pengamatan, dan refleksi pada siklus kedua.

Peneliti menggunakan dua sumber data yaitu sumber data primer dan sumber data sekunder. Sumber data primer adalah sumber data yang langsung digali dari subyek penelitian yaitu rekaman penelitian pembelajaran. Sedangkan sumber data sekunder adalah data yang diperoleh melalui perantara atau pihak lain (dalam hal ini teman sejawat). Selain itu data sekunder 
dalam penelitian ini adalah hasil wawancara dengan guru, dan hasil ulangan harian pokok bahasan sebelumnya yang diperoleh dari data dokumen guru Kelas VI.

\section{HASIL DAN DISKUSI}

Penelitian ini adalah penelitian tindakan kelas yang bertujuan untuk mengetahui bagaimana penerapan metode demonstrasi, aktivitas siswa selama penerapan metode demonstrasi, dan bagaimana hasil belajar siswa setelah proses pembelajaran dengan penerapan metode demonstrasi. Berdasarkan data yang diperoleh, maka akan dibahas penerapan pembelajaran, aktivitas siswa selama proses pembelajaran dan hasil belajar siswa selama penerapan metode demonstrasi. Penerapan metode demonstrasi berjalan dengan baik, meskipun ada beberapa hambatan yang dihadapi namun hambatan tersebut dapat diselesaikan pada pertemuan selanjutnya.

Prosedur penggunaan metode demonstrasi yang harus dilakukan dalam pembelajaran sebagai berikut. Pertama, mempersiapkan alat bantu yang akan digunakan dalam pembelajaran. Kedua, memberikan penjelasan tentang topik yang akan didemonstrasikan. Ketiga, pelaksanaan demonstrasi bersamaan dengan perhatian dan peniruan siswa. Keempat, penguatan (diskusi, tanya jawab dan atau latihan) terhadap hasil demonstrasi. Kelima, langkah-langkah pembelajaran IPA menggunakan metode demostrasi adalah sebagai berikut:

\section{Kegiatan Awal}

a. Pre-test.

b. Sebagai motivasi siswa diberi kuis yang berhubungan dengan gaya dan gerak benda.

\section{Kegiatan Inti}

a. Siswa memperhatikan penjelasan guru tentang gaya dan gerak.

b. Guru mendemonstrasikan cara membuat model jungkat jungkit

c. Siswa dibagi menjadi 3 kelompok. d. Setiap kelompok menirukan cara membuat model jungkat jungkit

e. Guru memberikan soal untuk didiskusikan dalam kelompok

f. Setiap kelompok mendiskusikan soal yang diberikan guru yang diberikan guru.

g. Masing-masing kelompok mengumpulkan tugas kelompok yang diberikan guru

h. Guru membahas hasil diskusi kelompok

i. Guru memberi penghargaan kepada kelompok yang paling cepat mengerjakan dan mendapat nilai benar paling banyak.

\section{Kegiatan Akhir}

a. Siswa mengerjakan soal individu.

b. Pada kegiatan akhir guru menutup pembelajaran dengan memberikan pesanpesan moral.

Selama pembelajaran IPA menggunakan metode demonstrasi guru dibantu observer (teman sejawat) mengamati aktivitas siswa. Aktivitas siswa yang diamati dalam penelitian ini meliputi, aktivitas memperhatikan, aktivitas menirukan membuat jungkat-jungkit, dan aktivitas kerjasama dalam kelompok. Hasil observasi aktivitas siswa dapat dilihat pada tabel berikut:

Tabel 1

Persentase Aktivitas Siswa

\begin{tabular}{llll}
\hline No & Aktivitas siswa & Siklus I & Siklus II \\
\hline 1 & Memperhatikan & $78,12 \%$ & $93,75 \%$ \\
2 & $\begin{array}{l}\text { Membbuat jungkat- } \\
\text { jangkit }\end{array}$ & $62,50 \%$ & $84,37 \%$ \\
3 & $\begin{array}{l}\text { Melakukan } \\
\text { kerjasama }\end{array}$ & $68,75 \%$ & $81,25 \%$ \\
\hline
\end{tabular}

Sumber: Olahan Data Penelitian, 2020

Hasil observasi aktivitas siswa pada siklus I, yaitu: aktivitas memperhatikan sebesar 78,12\%, aktivitas menirukan membuat jungkat-jungkit sebesar $62,50 \%$, dan aktivitas melakukan kerjasama dalam kelompok 68,75\%. Sedangkan pada siklus yang ke II, aktivitas memperhatikan sebesar 93,75\%, aktivitas menirukan membuat jungkat jungkit sebesar 84,37\%, dan aktivitas melakukan kerjasama dalam kelompok $81,25 \%$. 
Dalam penelitian ini siswa diberikan 3 kali tes, yaitu tes pendahuluan (Pra Siklus), tes Akhir siklus I dan tes Akhir Siklus II. Bentuk soal dari masing-masing tes adalah tes uraian. Masing-masing tes terdiri atas 10 soal isian dengan skor 1 jika benar, dan 0 jika salah. Hasil belajar siswa pada penelitian ini mengalami peningkatan. Hal tersebut dapat dilihat pada ketuntasan hasil belajar siswa yang ditunjukkan pada tabel berikut ini:

\section{Tabel 2}

Peningkatan Hasil Belajar Siswa

\begin{tabular}{ccccc}
\hline No & $\begin{array}{c}\text { Kategori hasil } \\
\text { belajar }\end{array}$ & $\begin{array}{c}\text { Pra } \\
\text { siklus }\end{array}$ & $\begin{array}{c}\text { Siklus } \\
\text { I }\end{array}$ & $\begin{array}{c}\text { Siklus } \\
\text { II }\end{array}$ \\
\hline 1 & $\begin{array}{c}\text { Tuntas } \\
\text { memenuhi }\end{array}$ & 46,87 & 75,00 & 96,87 \\
& KKM 65 & & & \\
2 & $\begin{array}{c}\text { Tidak tuntas } \\
\text { memenuhi } \\
\text { KKM 65 } \\
3\end{array}$ & 53,13 & 25,00 & 3,13 \\
& Total & 100 & 100 & 100 \\
\hline Sumber: Olahan Data Penelitian, 2020 & &
\end{tabular}

Berdasarkan tabel persentase hasil belajar siswa di atas, diketahui bahwa hasil belajar siswa yang tergolong dalam kategori tuntas pada tes pendahuluan hanya $46,87 \%$ (5 Siswa), siklus I sebesar 75,00\% (7 Siswa) sedangkan pada siklus II mencapai $96,87 \%$ (10 Siswa), dengan demikian kategori hasil belajar siswa yang tergolong tuntas mengalami peningkatan sebesar $21,87 \%$. Hasil belajar siswa yang tergolong dalam kategori tidak tuntas pada siklus I sebesar 25,00\% (3 Siswa) sedangkan pada siklus II sebesar 3,13\% (0 Siswa) dengan demikian kategori hasil belajar siswa yang tergolong tidak tuntas mengalami penurunanan sebesar 21,87\%.

Metode demonstrasi adalah cara penyajian pelajaran dengan memperagakan atau mempertunjukkan kepada peserta didik suatu proses, situasi atau benda tertentu yang sedang dipelajari baik dalam bentuk sebenarnya maupun dalam bentuk tiruan yang dipertunjukkan oleh guru atau sumber belajar lain yang ahli dalam topik bahasan " (Sumantri, (Roetiyah, 2001). Menurut Suaedy (2011) metode demonstrasi adalah suatu cara penyampaian materi dengan memperagakan suatu proses atau kegiatan. Pengertian metode demonstrasi menurut Syah (2000) adalah metode mengajar dengan cara memperagakan barang, kejadian, aturan dan urutan melakukan kegiatan, baik secara langsung maupun melalui penggunaan media pengajaran yang relevan dengan pokok bahasan atau materi yang sedang disajikan.

Dari pengertian di atas, dapat disimpulkan bahwa metode demonstrasi adalah adalah metode mengajar yang menggunakan peragaan untuk memperjelas suatu pengertian atau untuk memperlihatkan bagaimana melakukan sesuatu kepada anak didik atau cara guru dalam mengajar dengan memperagakan dan mempertunjukkan kepada siswa suatu proses, situasi, kejadian, urutan melakukan suatu kegiatan atau benda tertentu yang sedang dipelajari baik dalam bentuk yang sebenarnya maupun tiruan melalui penggunaan berbagai macam media yang relevan dengan pokok bahasan untuk memudahkan siswa agar kreatif dalam memahami materi.

\section{KESIMPULAN}

Berdasarkan hasil penelitian dan pembahasan yang telah diuraikan, maka dapat disimpulkan sebagai berikut:

1. Penerapan metode demostrasi pada pelajaran IPA materi gaya dan gerak pada siswa kelas VI SDI Habiratin berjalan dengan baik, siswa tertarik dalam mengikuti pelajaran. Dalam pembelajaran ini kegiatan pembelajarannya disusun sesuai dengan tahap-tahap dalam perencanaan yang telah dibuat.

2. Penerapan metode demostrasi pada pelajaran IPA materi gaya dan gerak pada siswa kelas VI SDI Habiratin dapat meningkatkan keaktifan siswa dalam pembelajaran. Hal tersebut dapat ditunjukkan pada analisis aktifitas siswa dalam pembelajaran dengan penerapan metode demostrasi pada pelajaran IPA 
materi gaya dan gerak pada siswa kelas VI

SDI Habiratin, yaitu Aktivitas

memperhatikan meningkat sebesar $15,63 \%$, aktivitas menirukan membuat jungkat-jungkit meningkat sebesar $21,87 \%$, dan aktivitas melakukan kerjasama dalam kelompok 12,50\%.

3. Penerapan metode demostrasi pada pelajaran IPA materi gaya dan gerak pada siswa kelas VI SDI Habiratin dapat meningkatkan hasil belajar siswa yang diperoleh dari persentase ketuntasan pada siklus 1 sebesar 75,00\% (tuntas) dan pada siklus 2 sebesar $96,87 \%$ (tuntas). Sehingga hasil belajar meningkat $21,87 \%$

\section{REFERENSI}

Depdiknas. (2006). Peraturan Menteri Pendidikan Nasional No. 22 Tahun 2006 Tentang Standar Isi Untuk Satuan Pendidikan Dasar dan Menengah. Jakarta: Departemen Pendidikan Nasional.

Sudjana, Nana. (2008). Penilaian Hasil Proses Belajar Mengajar. Bandung: Remaja Rosdakarya.

Sunardi. (2010). Penelitian Tindakan Kelas dalam Modul Bidang Studi Guru Kelas . Jember: Universitas Jember.

Trianto. (2010). Mengembangkan Model Pembelajaran Tematik. Jakarta: PT. Prestasi Pustakaraya

Hadi. (2003). Pembelajaran dengan Pendekatan Realistik. Program Pasca Sarjana Universitas Negeri Malang. Malang.

Ismail. (2003). Media Pembelajaran (ModelModel Pembelajaran). Direktorat Pendidikan Lanjutan Pertama. Jakarta.

Inganah, S. (2003). Model Pembelajaran Segi Empat dengan Pendekatan Matematika Realistik. Pasca Sarjana Universitas Negeri Malang. Malang.

Kasbolah K. (1998). Penelitian Tindakan Kelas (PTK). Departemen Pendidikan dan Kebudayaan LBRD Loan. Jakarta.

Jennings, Sue \& R, Dunne. (1999). Math

Stories, Real Stories, Real-life Stories. 